AperTO - Archivio Istituzionale Open Access dell'Università di Torino

Challenging gender perspective in the community to promote well-being and health.

This is a pre print version of the following article:

Original Citation:

Availability:

This version is available http://hdl.handle.net/2318/1734876

since $2020-04-02 T 12: 47: 21 Z$

Published version:

DOI:https://doi.org/10.1080/10852352.2019.1624352

Terms of use:

Open Access

Anyone can freely access the full text of works made available as "Open Access". Works made available under a Creative Commons license can be used according to the terms and conditions of said license. Use of all other works requires consent of the right holder (author or publisher) if not exempted from copyright protection by the applicable law. 


\title{
Challenging gender perspective in the community to promote well-being and health
}

\author{
Laura Migliorini*, Norma De Piccoli** \\ * Department of Education Sciences, University of Genoa, Italy \\ ** Department of Psychology, University of Turin, Italy
}

\begin{abstract}
Community is an excellent potential arena to challenge gender perspective and change power structures in society because of its pivotal role in socializing on gender and on shape social context. The community influences the availability of positive and negative role models, and the accessibility to specific settings the ease with which relationships are formed and a variety of emotions and attitudes. The literature shows that to pay attention to gender equity affect numerous indicators of community well-being. The attention to gender equity make community more competent in order to create human and social capital that enables community well-being. We'll examine: the role of gender not only as social construction but also as context to create healthy setting in the community; the health and illness in gender perspective that scientific domain seems to have some resistances to a cultural scientific change.
\end{abstract}

Keywords: gender perspective, well-being, health, community

The question we take up in this paper is referred to an interdisciplinary and intersectional scientific debate, illustrating on the one hand the need for a careful look at gender differences and inequalities, on the other, by presenting disciplinary fields and perspectives in which this attention still seems to be at the beginning. We refer to a theoretical and epistemological perspective that has its foundations in an 
Running head: GENDER PERSPECTIVE AS PROMOTION OF WELL-BEING AND HEALTH

ecological analysis of human behavior; in particular, we propose the idea that a perspective focusing on gender allows to reconsidered approaches related to intervention and prevention and, therefore, related to well-being and health.

Before developing these considerations, we will present a brief summary that illustrates both at what point is the scientific debate on the theme of gender, and some considerations on living conditions that differentiate men from women, in order to place these theoretical reflections in contemporary context. If the question of gender is a question of similarity or difference is an aspect that already some years ago some authors posed. In 2004 Eagly, Wood and Johannesen-Schmidt asked: "Why do human females and males behave differently in some circumstances and similarly in others?" (p. 269), sustaining that social role theory give a comprehensive answer to this question. The interest is not to support a principle of similarity or of difference between gender, but rather to analyze the reasons and consequences of similarity as well as differences (presumed or objectively identified, as we shall see).

About the differences, gender gap in the world is changed over time, but different forms of inequity and discrimination still exist to the detriment of women: economical gap, different opportunities to access to the top of power places (the glass ceiling), both in political domain and in private sector, different involvement in caregiving and in the work/house conciliation and other example we could to remember, in order to testify that between man and women the road of equity is still long (Barreto, Ryan, \& Schmitt, 2009; Richman, VanDellen, \& Wood, 2011).

About health and well-being WHO (2016) states that general condition of women's health in Europe is good, women have made great progress in equality and in relation of social, economic and contextual factors that affect on women's health and well-being. However, this condition is not homogeneous and health inequities are still remaining in Europe in certain groups of women continuing to be more exposed at health risk with lower well-being scores. 
Running head: GENDER PERSPECTIVE AS PROMOTION OF WELL-BEING AND HEALTH

These considerations have, or should have, political implications, but necessarily also scientific, according to an interdisciplinary perspective, to investigate the repercussions these differences have not only on the minority group (in this case the female gender), but also on the whole system. According to Klaus Schwab, Founder and Executive Chairman of the World Economic Forum when women and girls are not integrated - as both beneficiary and shaper - the global community loses. We believe that the community, in the sense of the local community, constitutes an interesting observation point for developing this reflection, since the community constitutes the microcosms in which it is possible to construct and de-construct power structures. Furthermore, the community, that is the environment in which people live, build and develop social relations, is the "setting" in which the daily action of anyone is realized, but especially for women. Stafford, Cummins, Macintyre, Ellaway, and Marmot (2005) show that the residential environment is more important for women's health and well-being than for men, also because the social roles typically fulfilled by women, such as childrearing and maintaining the home, it makes that women spent much of their time in the neighbourhood (Rollero, Gattino, \& De Piccoli, 2014).

Another reflection that emphasizes how women have a different presence in the local community derives from scholars that have studied political and social participation. We know that political participation is lower for women compared to men; this difference is attenuated if we look at the social involvement, because women prefer a social commitment rooted in the local boundaries (Onyx \& Leonard, 2000). Another differences showing a gender difference is related to the type of social/political involvement; women prefer to be involved in direct care and less in public/ political activities (Wilson, 2000; De Piccoli \& Rollero, 2010), confirming that women play a major role in care tasks not only in the family (Ferree, 2010; Migliorini, Rania, Cardinali, Guiducci, \& Cavanna, 2015; Rania, Migliorini, Rebora, \& Cardinali, 2015) but also in relationships with the contexts and the community. In particular, in the promotion and prevention at the community level, the role of 


\section{Running head: GENDER PERSPECTIVE AS PROMOTION OF WELL-BEING AND HEALTH}

women is crucial for the well-being of the community (i.e. community programs "mother to mother" Williamson, Knox, Guerra, \& Williams, 2014), however often in health promotion and prevention approaches, gender is an issue that is often ignored (Östlin, Eckermann, Mishra, Nkowane, \& Wallstam, 2006). Even when the community is negative for the individual and for the minor, women and mothers play a decisive role in developing that sense of negative community can protect their children (Brodsky, 1996). Therefore, the relationship between women and the community could be considered contradictory; because, on the one hand, the public sphere, and hence the community, has traditionally been linked to the male role, on the other hand studies showed that the community is the place and the context in which women have an active and relevant role (Wilson, 2000; De Piccoli, \& Rollero, 2010).

Analyzing gender perspective within the community in order to understand well-being process is extremely difficult and complex. To see what a gender perspective brings to community approach and studies, it first necessary to recognize the transformation of the community, because communities are extremely fluid context (Bauman, 2000), and this “fluidity" characterizes modern communities both for the increasing complexity of contemporary society, and for the profound transformations of welfare systems.

Gender perspective could encourage community psychology to think about gender as central to their understanding community process and dynamic. Recently Bond and Allen (2016) propose to overcome the paradigm of "difference" to get to a more complex and multifaceted understandings of gender.

To propose some stimuli around this issue, we focus the reflection choosing two topics that are central, according to us, to deeper a gender perspective rooted in the community, according to an ecological perspective. The first is related to gender role: as it is well known, gender refers to the societal and cultural construction of biological characteristics and because gender is built by and into a social and cultural context, we find interesting the perspective proposed by Bond and Wasco (2017), to consider 
Running head: GENDER PERSPECTIVE AS PROMOTION OF WELL-BEING AND HEALTH

gender as context. The second topic is related to describe how sex and gender in health sector is considered, because in this scientific context, resistances to a change of perspective seem to persist.

\section{Gender as social construction and as context}

The concept of role provides a basis for defining the relationship between a person and its social environment. The role of a person defines the functional meaning of a person in different contexts and is useful for understanding the problems of adaptation within a modality of approach. Psychological characteristics of men and women are affected also by their social roles. According to Wood and Eagly (2012) people within a society observe the actions of men and women and form beliefs about their psychological attributes, on these bases they infer gender stereotypes inside social psychological processes. Inside perspective of social role theory gender stereotypes are not fixed but can be changed through changes in the social roles of woman and men. Within this perspective, attention is paid to the role of women in the tasks of care in their multiple social characteristics (family, educational welfare also from the occupational point of view). For a long time, invisible in its obviousness, it had not been considered as a matter of study because it was taken for granted, it was not recognized by complexity, was summed up in other aspects, as maternity, or embedded in other activities. And even today that women remain the key determinant to care (APA, 2009), and this female social action has only been partially modified. The caregiving role is becoming increasing relevant because chronicity of illness and the aging of the population, the need for the recipient and for the caregivers and the value it holds, not only at the individual or family level, but for the whole society. According to Lee (1999) informal familybased care of adults produce a significant burden on caregivers regarding subjective wellbeing, preventive behaviours, lifestyle and employment that could affect women life. In fact, the majority of family caregivers are women, and the gender inequities are perpetuated by an assumption that family caregiving is naturally linked to the woman role and identity 


\section{Running head: GENDER PERSPECTIVE AS PROMOTION OF WELL-BEING AND HEALTH}

Gender identity reflects people's understanding of themselves in terms of cultural definitions of female and male. According to Wood and Eagly (2015) there are two traditions of research on gender identity that describe gender roles. The personality approach to gender identity regarding different traits and interests and the gender self-categorization approach that includes identification with the social category of women or men. Each approach should be related to behaviors within the relevant domain. Both traditions contribute understanding that gendered self-concepts is connected with social roles and individual cognitions, emotions, and behaviors (Eagly \& Wood, 2010; Wood \& Eagly, 2015).

Furthermore, recent contributions (Bond \& Allen, 2016; Bond \& Wasco 2017; Bond, Serrano-Garcia, \& Keys, 2017) allowed considering the gender as context by emphasizing how gender could be considered a rooted in the various social settings in which we are involved. Therefore, it's possible delineating framework for understanding and addressing "gendered qualities of settings". For Edison Trickett (1996) twenty years ago indicated how the future of community psychology could be identified in the context of diversity and diversity contexts emphasizing the importance of encouraging both theoretical and research viewpoints, as well as from the point of view of application and intervention, and an analysis of communities within their sociocultural framework. In the spirit of heeding Trickett's (1996) Bond (1999; 2016) explore two themes as important aspects of contexts for supporting diversity: the culture of relationship and acknowledgment of multiple realities.

Bond and Allen (2016) suggests that gender inequality can become rooted in social settings when system dynamics establish different setting on the bases of gender, when the fact that a gender group is privileged over the others is perceived as normal, and when the inequity is not to cope related as gender modify the access to power and resources. These dynamics are referred to as setting qualities and practices that for community psychologist are relevant to understanding of what influences actions, behaviors and emotion (Levine, Perkins, \& Perkins, 2005). These practices include the habits in which context are structured, form relational patterns, and promote and enhance specific values. This perspective is based on the 
Running head: GENDER PERSPECTIVE AS PROMOTION OF WELL-BEING AND HEALTH

ecology of lives, the relevance of social settings and their impact on behavior and community intervention (Trickett, 2009).

The analysis proposed by Bond and Allen (2016) seem well linked to the critic to an analysis considering gender "somehow separable from other aspects of social identity, such as race, and social class" (Shields, 2016, p. V).

\section{Sex and gender in health research}

Why some considerations around the topic of gender differences in health researches? Because the "gender question" in health research and in health domain is in general controversial.

From one side we have many data showing gender inequity in the world and in the western world too; we know that, at least in the western world, women live longer, but declare a worse quality of life and well-being compared to men; epidemiological data show the pathologies in which there are similarities and those in which there are differences between men and women. At the basis of the differences there is an explanation in terms of bio-psycho-social factor that co-occur in this phenomenon. From another side because in health domain, in particular in medicine domain, an androcentric model of science is still present. Moreover, in health sector the distinction between "sex" and "gender" is not yet clearly shared; Short, Yang, and Jenkins (2013) declare that the two terms are used interchangeably in research on health, and Risberg, Johansson, and Hamberg (2009) underline that the term gender, in medicine, is often used as a synonym for biological sex, while the concept of gender, as it is well known, is much broader and more extensive than mere biological differences between men and women.

In health and medical sector, the question is actual and problematic and it is object of a deep scientific and political debate (Gattino, De Piccoli, \& Rollero, 2018).

As Hammarstrom (2007) clearly writes "Both social and biological factors need to be problematized from a societal and constructivist framework (...) Compared with gender research in other disciplines, 
Running head: GENDER PERSPECTIVE AS PROMOTION OF WELL-BEING AND HEALTH

analyzing the interplay between sex and gender is especially significant in medicine, where biological factors obviously are important" (p. 124). Biological and social factors should be considered jointly because the biological could be socially determined and vice-versa "biological sex is seen to influence health by modifying one's behavior and lifestyle and gender-behavior can modify biological factors and thereby health" (Ludwig, Oertelt-Prigione, Kurmeyer, Gross, Gruters-Kieslich, Regitz-Zagrosek, \& Peters, 2015, p. 997).

"Gender is rooted in biology and shaped by environment and experience" (Wizemann \& Pardue, 2001, p.17) and "sex" is not a pure bodily and material fact, "but it is deeply interwoven with social and cultural constructions of gender" (Kaiser, Haller, Schmitz, \& Nitsch, 2009, p. 50). To underline this complex interrelation Krieger (2003, p. 653) proposes the notion of "biologic expression of gender" and "gendered expression of biology".

If on the one hand, therefore, there is a need to develop the studies paying attention to specify the differences in sex, gender and their interrelation, on the other hand the risk of reductionism underlying the sex/gender dichotomy is denounced. According to Hammarström, Johansson, Annandale and coll. (2014), the concepts referred to health in a gender perspective are manifold; it is not just about concepts like sex and gender, but also about intersectionality, embodiment, gender equity and gender equality. These concepts are intertwined with each other but they are also "problematic and ambiguous in health science", as the authors declare (p. 185).

Intersectionality refers to the multiplicity of dimensions to which the individual belongs to, that is gender, class, ethnicity, sexuality, age, etc. should be considered and analyzed according to a contextual perspective and, we say, according to a systemic-ecological analysis. The concept of embodiment has its roots in phenomenology and considers the body-mind a holistic unit. Gender has its reason to exist because the individual live in a body (male or female) that has a value according to social norms and 
Running head: GENDER PERSPECTIVE AS PROMOTION OF WELL-BEING AND HEALTH

values. Since James' analysis on identity we know the psychological and social importance that the body has for the individual, but this is not the aim of this study.

Finally, the difference between gender equity and gender equality seems to us relevant. Following the synthesis proposed by Hammarström, 2014 et coll. "Gender equality concerns equal rights (absence of gendered discrimination) while gender equity concern's needs-based approaches (p. 187) (...). We argue that gender equality should be defined as absence of discrimination and gender equity as meeting the needs of women and men, whether similar or different" (p. 188).

Therefore, the importance of gender perspectives in health science is increasing, but undoubtedly needs to be developed according to a perspective that sees sex and gender differences strictly inter-related to other dimensions, according to a relational perspective, such as that proposed by Connell (1987): “(he) emphasizes that gender relations are not based on individual characteristics, but rather on the structurally organized relationships between men and women in society. The gender order in society is the basis for society's gendered division of production, power relations, and emotional relations, as well as the gendered dimensions of symbolism and culture" (Hammarström, 2007, p. 124).

\section{Conclusion}

Scientific literature and social action have indicated the need to build actions capable of influencing the relationship between subject and living environments, and the relationship between women and living environments can be considered uncommon and sometimes contradictory. Try to influence social environments in order to influence the problem at the center of the intervention Maton (2000) identifies four dimensions of intervention: relational, instrumental, structural, and cultural. Community psychology assumes the goal of empowerment as a growth process based on increasing self-esteem, self-efficacy, "power," to raise resources and appropriate their potential (Zimmerman, 2000). All of this is strongly 


\section{Running head: GENDER PERSPECTIVE AS PROMOTION OF WELL-BEING AND HEALTH}

linked to the growth of resources, the extension of relational skills, and social integration towards individuals, groups and communities. This analysis involves deeply social policies; we consider it is important a link between politics, local and international organizations (from associations rooted in the local community to international organization, such as WHO) and research. If this sectors act separately it is not possible to change; health and well-being have origin in the community and they find resources and opportunities to evolve in the quality of the environment and in the equity of opportunity. "If public health has an ethical responsibility to reduce social inequalities, then it must be considered unethical not to include the sex and gender dimension, where appropriate, in research for the benefit of both men and women. Targeted gender-fair public health programs can only be built on the basis of gender-oriented research" (Lawrence \& Rieder, 2007, p. 99).

Then it is necessary to develop a gender-oriented research that overcomes the binarism male/female. LaFrance, Levy Paluck, \& Brescoll (2004) underlined that “concentrating on sex differences and ignoring other group differences tends to obfuscate factor that may better explain many psychological phenomena. At least, examining differences among groups of women and men may help untangle the relative influence of sociocultural and biological factors on sex differences, because society exposes different groups to different experiences" (p. 340).

Recently, Shields (2016), according to a feminist perspective, states that "we are in a transformative moment in the study of the psychology of gender (...). New theories, questions, and methods are challenging old conventions in the psychology of gender. The time is ripe to shift the discussion of gender from an often non-theoretically driven exploration of whether differences exist to issues that cut closer to the bone. These include, for example, intersectionality theory (Grzanka, 2014; Warner, Settles, \& Shields, 2017), trans* problematizing of gender binaries, and new neuroscientific findings (e.g. Richardson, 2013) that shatter psychological conventions built on a model of gender that assumes two fixed and non-overlapping gender categories" (p. V). 
Running head: GENDER PERSPECTIVE AS PROMOTION OF WELL-BEING AND HEALTH

To conclude, also as a wish for an immediate future, gender researchers challenge scholarship on community to bring the gender consciousness to well-being and health community research and intervention, promoting different and intersectional interventions, and apply research to community and health to promote fairness and equity in the context trough gender lens.

\section{References}

American Psychological Association. UN Report. Washington D.C: American Psychological Association; 2009. Gender equality in caregiving: The United Nations response.

Barreto, M., Ryan, M. K., \& Schmitt, M. T. (Eds.). (2009). Psychology of women book series. The glass ceiling in the 21st century: Understanding barriers to gender equality,

Bauman, Z. (2000) Liquid Modernity. Cambridge: Polity.

Bond M. (1999) Gender, race, and Class in Organizational Contexts, American Journal of Community Psychology, 27, 3, 327-355.

Bond, M.A., \& Wasco, S.M. (2017). Gender as context: A framework for understanding and addressing gendered qualities of settings. American Psychological Association, pp. 369 - 385.

Bond, M.A., Serrano-Garcia, I., \& Keys, C. (2017). Handbook of Community Psychology Volume 1: Theoretical Foundations, Core Concepts, and Emerging Challenges. American Psychological Association Press, 1:

Bond, M.A., \& Allen, C. (2016). Beyond Difference: Gender as a Quality of Social Settings. In: Feminist Perspectives on Building a Better Psychological Science of Gender pp. 231

Bond, M.A. (2016). Leading the way on diversity: Community psychology's evolution from invisible to individual to contextual. American Journal of Community Psychology, 58:3-4 pp. 259 - 268

Brodsky, A. (1996). Resilient single mothers in risky neighbourhoods: Negative psychological sense of community. Journal of Community Psychology, 16, 771-91 
Running head: GENDER PERSPECTIVE AS PROMOTION OF WELL-BEING AND HEALTH

Chrisler J.C., \& McCreary D.R. (Eds.). (2010). Handbook of Gender Research in Psychology, DOI 10.1007/978-1-4419-1467-5_26, Springer Science Business Media, LLC.

Connell R.W. (1987). Gender and Power: Society, the Person and Sexual Politics. Stanford, Calif: Stanford University Press.

De Piccoli, N., \& Rollero, C. (2010). Public Involvement in Social and Political Participation Processes: A Gender Perspective. Journal of Community \& Applied Social Psychology, 20: 167-183.

Eagly, A.H., Wood, W., \& Johannesen-Schmidt, M.C. (2004). Social Role Theory of Sex Differences and Similarities, in Eagly A.H., A.E. Beall, R.J. Sternberg (Eds.). The Psychology of Gender. Second Edition, The Guilford Press, New York, pp. 269- 295.

Ferree M.M. (2010). Filling the glass: Gender perspective on Families. Journal of Marriage and Family, 72, 420-439, DOI:10.1111/j.1741-3737.2010. 00711.x

Gattino, S., De Piccoli, N., \& Rollero, C. (2018). Awareness of Gender Medicine among family doctors. A field investigation. In press

Grzanka, P. R. (2014). (Ed.) Intersectionality. Boulder, CO: Westview Press.

Hammarström, A. (2007). A Tool for Developing Gender Research in Medicine: Examples from the Medical Literature on Work Life. Gender Medicine, vol. 4, suppl. B, 123-132.

Hammarström A, Johansson K, Annandale E, et al (2014). Central gender theoretical concepts in health research: the state of the art. J Epidemiol Community Health; 68:185-190.

Kagan, C., Burton, M., Dunckett, P., Lawthon, R., \& Siddique, A. (2011). Critical community psychology. Padstow, UK: Blackwell.

Kaiser, A., Haller, S., Schmitz, S., Nitsch, C. (2009). On sex/gender related similarities and differences in fMRI language research. Brain Research Review, 61 (2), 49-59.

Krieger, N. (2003). Genders, sexes, and health: what are the connections - and why does it matter? International Journal of Epidemiology, 32 (4), 652-657. 
Running head: GENDER PERSPECTIVE AS PROMOTION OF WELL-BEING AND HEALTH

LaFrance, M., Levy Paluck, E., \& Brescoll V. (2004). Sex Changes, in Eagly A.H., A.E. Beall, R.J. Sternberg (Eds.). The Psychology of Gender. Second Edition, The Guilford Press, New York, pp. 328344.

Lee (1999) Health, Stress and Coping among Women Caregivers. A Review, Journal of Health Psychology,

Levine, M., Perkins, D.V., \& Perkins, D.D. (2005) Principles of Community Psychology. Perspective and application, Oxford University Press.

Lawrence, K., \& Rieder, A. (2007). Methodological and ethical ramification of sex and gender differences in public health research. Gender Medicine; 4 Suppl. B: S 96-105.

Ludwig, S., Oertelt-Prigione, S., Kurmeyer, C., Gross, M., Gruters-Kieslich, A., Regitz-Zagrosek, V., Peters H. (2015). A Successful Strategy to Integrate Sex and Gender Medicine into a Newly Developed Medical Curriculum, Journal of Women's Health, Volume 24, Number 12.

Maton, K.I. (2000). Make a difference. American Journal of Community Psychology, 28, 25-57.

Migliorini, L., Rania, N., Cardinali P., Guiducci V., Cavanna D. (2015) Comparing maltreating and foster families in Italian context. Journal of Child and Family Studies. 25, 746-755. Doi: 10/1007/s10826015-0269-5

Östlin, P., Eckermann, E., Mishra, U. S., Nkowane, M., Wallstam, E. (2006) Gender and health promotion: a multisectoral policy approach. Health Promotion International. 21:25-35.

Onyx, J., \& Leonard, R. (2000). Women, volunteering and social capital. In J. Warburton, \& M. Oppenheimer (Eds.), Volunteers and volunteering. Sidney: Federation Press.

Rania, N., Migliorini, L., Rebora S., Cardinali P. (2015). Daily family routine of Italian and Ecuadorian immigrant mothers in everyday life: a qualitative approach using diaries and interviews. Sage open, 1-13. DOI: 10.1177/2158244015609411; http://dx.doi.org/10.1177/2158244015609411 
Running head: GENDER PERSPECTIVE AS PROMOTION OF WELL-BEING AND HEALTH

Richardson, S. S. (2013). Sex itself: The search for male and female in the human genome. Chicago: University of Chicago Press.

Richman, L. S., VanDellen, M., \& Wood, W. (2011). How women cope: Being a numerical minority in a male-dominated profession. Journal of Social Issues, 67, 492-509.

Risberg, G., Johansson, E.E., \& Hamberg, K. (2009). A theoretical model for analysing gender bias in medicine. International Journal for Equity in Health, 8, 28, doi:10.1186/1475-9276-8-28.

Rollero, C. Gattino, S., \& De Piccoli, N. (2014). A gender lens on Quality of Life: The Role of Sense of Community, Perceived Social Support, Self-Reported Health and Income. Social Indicators Research, DOI 10.1077/s11205-013-0316-9.

Shields, S.A. (2016). Feminist Psychological Science and the Future of Gender Research in Roberts T.A., Curtin N., Duncan L.E., Cortina L.M. (eds.). Feminist Perspectives on Building a Better Psychological Science of Gender, Springer, Switzerland.

Short, S.E., Yang, Y.C., \& Jenkins, T.M. (2013). Sex, Gender, Genetics, and Health. American Journal of Public Health, 103, 51, 593-601.

Stafford, M., Cummins, S., Macintyre, S., Ellaway, A., \& Marmot, M. (2005). Gender differences in the association between health and neighborhood environment. Social Science \& Medicine, 60, 16811692

Trickett E.J. (1996) A Future for Community Psychology: The Contexts of Diversity and the Diversity of Contexts, American Journal of Community Psychology, 24(2) (1996): 209-234.

Trickett E.J. (2009) Community psychology: individuals and interventions in community context. Annu Rev Psychol. 60:395-419. doi: 10.1146/annurev.psych.60.110707.163517.

Wilson, J. (2000). Volunteering. Annual Review of Sociology, 26, 215-240. 
Running head: GENDER PERSPECTIVE AS PROMOTION OF WELL-BEING AND HEALTH

Warner, L.R., Settles, I.H., \& Shields, S.A. (2017). Intersectionality theory in the psychology of women. In C. Travis \& J. W. White (Eds.). American Psychological Association Handbook on the Psychology of Women. Washington, DC: American Psychological Association.

Wizemann, T.M., \& Pardue, M.L. (eds.). (2001). Exploring he biological contributions to human health: Does sex matter? Washington DC: National Academy of Science.

Williamson, A. A., Knox, L., Guerra, N. G., \& Williams, K. R. (2014). A pilot randomized trial of community-based parent training for immigrant Latina mothers. American Journal of Community Psychology, 53(1-2), 47-59. http://dx.doi.org/10.1007/s10464-013-9612-4

Wood, W., \& Eagly, A.H. (2010). Gender. In S. T. Fiske, D. T. Gilbert, \& G. Lindzey (Eds.), Handbook of social psychology (Vol. 1, 5th ed., pp. 629-667). New York: Wiley

Wood, W., \& Eagly, A.H. (2015). Two traditions of research on gender identity. Sex Roles, 73, 461473.http://dx.doi.org/10.1007/s11199-015-0480-2

Wood, W., \& Eagly, A.H. (2012). Biosocial construction of sex differences and similarities in behavior. In M. P. Zanna \& J. M. Olson (Eds.), Advances in Experimental Social Psychology. San Diego, CA: Academic Press.

World Health Oorganization (2016). Women's health and well-being in Europe: beyond the mortality advantage. WHO Regional Office for Europe, Copenaghen.

World Economic Forum (2017). The Global Gender Gap Report, Geneva, Switzerland.

World Health Organization, Commission on Social Determinants of Health. (2008). Closing the gap in a generation.

Zimmerman, M. A. (2000). Empowerment theory: Psychological, organizational, and community level of analysis. In (eds.) J. Rappaport, E. Seidman. Handbook of Community Psychology. New York: Kluwer/Plenum. 